\title{
THE HYDE WE LIVE IN: STEVENSON, EVOLUTION, AND THE ANTHROPOGENIC FOG
}

\author{
By Pascale McCullough Manning
}

IN MULTIPLE ENTRIES IN HIS notebooks, Robert Louis Stevenson pauses to consider the failure of scientific language to communicate the abstractions that undergird its theoretical models of natural processes. In failing to make the operations of the physical world speak, materialist discourse suffers from a terminological disorder. His diagnosis is sweeping and acerbic: "Scientific language like most other language is extremely unsatisfactory" ("Note Book" 300). In what follows I will argue that over the course of several key essays of the 1880s and his most famous work of fiction, Strange Case of Dr. Jekyll and Mr. Hyde (1886), Stevenson aims to redress the fundamental abstraction of the most prominent materialist doctrine of his day, Darwinian evolutionary theory, rendering it viscerally communicable in the figure of Hyde, who represents both the individual organism subject to the pervasive modifying forces of speciation and the embodiment, in a single yet fluctuating corporeal entity, of those very forces. ${ }^{1}$ Further to this, I will propose that in imagining Hyde's genesis at the laboratory table (the result of Jekyll's incursions into nature) and in placing Hyde in symbiosis with the London fog (the admixture of natural forces and human intervention in the form of the burning of fossil fuels), Strange Case can be added to the body of literature that hails the dawning of the Anthropocene, famously defined by Paul Crutzen as the "human-dominated geological epoch supplementing the Holocene" in which the human has become "a major environmental force" (23). The figure of Hyde thus manifests evolutionary forces in all their teeming presence while also harkening the new forms of subjectivity emerging from our catastrophic agency in the present era - one in which the human has become, in the words of Dipesh Chakrabarty, a "geophysical force" (13).

\section{I. "Vital putrescence of the dust": Making Evolution Visible}

WITH REFERENCE TO CHEMICAL formulae like $\mathrm{H}_{2} \mathrm{O}$ and $\mathrm{NH}_{3}$ - which he characterizes as "imponderable figures of abstraction" - Robert Louis Stevenson writes in his 1888 essay "Pulvis et Umbra" that "science carries us into zones of speculation, where there is no habitable city for the mind of man" (200). Thus troubled by the human mind's inability to find stable purchase in the "symbols and ratios" of chemical science, Stevenson reflects in his 
contemporaneous notebook upon how the language of scientific materialism so often fails to communicate "thought that transcends existing means of expression" ("Pulvis" 199; "Note Book" 301). While his notebook comments are largely directed at the unsatisfactory language of "the now proved dynamical hypothesis" (i.e., thermodynamics), and his statements in "Pulvis et Umbra" are addressed to the transformation of compounds or matter into formulae, in both instances Stevenson gives voice to a recurring preoccupation with the difficulties of representation in language, and specifically the failure of scientific terminology to adequately materialize theoretical abstraction and thus to "become communicable and practical" reality ("Note Book" 301). ${ }^{2}$

To Stevenson, indefiniteness, evanescence, and immateriality seem to be conditions not only of modern scientific language but, as a result of the findings of natural science, of modern existence. "There seems no substance to this solid globe on which we stamp," he writes, and gravity - "that swings the incommensurable suns and worlds through space" - is yet only "a figment varying inversely as the squares of distances," thwarting the mind's attempts to dwell in consideration of it ("Pulvis" 199-200). And yet, he says, these imponderables are bearing in on us: "Symbols and ratios carry us and bring us forth and beat us down" (199). In "Pulvis et Umbra" Stevenson would seem to yearn for the missing expressive link between, say, $\mathrm{F}=\mathrm{mg}$ and suns and worlds swinging through space. Thus, by the essay's third paragraph, scientific abstractions give way to a teeming verbal panorama spanning the inhospitable cosmos populated by "rotary islands, suns and worlds and the shards and wrecks of systems" and the expanse of geological time on earth from generative and elemental 'rot' to the emergence and development of animal and vegetable life (200). As throughout his nonfiction of the period, Stevenson remains preoccupied with motifs of human descent, but here for the first time - and evidencing the concept's powerful hold on his imagination - he surveys evolution more generally. In a letter to the critic Sidney Colvin, Stevenson describes "Pulvis et Umbra" as his "Darwinian Sermon," saying that "I think there is some fine writing in it, some very apt and pregnant phrases" (Letters 34). As if in answer to his notebook declarations that "terminology is the most important of all subjects" and that "[a]ny advance in thinking must be followed by advanced powers of expression," Stevenson's essay strives to render evolution a "habitable city for the mind of man" and shows its author identifying a lexicon through which to articulate the journey of evolving life, beginning with its emergence from the "natal mud" ("Note Book" 300; "Pulvis" 200).

The vigorous language of "Pulvis et Umbra" - in which the human, "fitted with eyes that move and glitter in his face," is "the disease of the agglutinated dust" - stirringly unpacks and materializes the abstractions of evolution through natural selection by envisioning variation, inheritance, competition, and struggle in accelerated terms, thereby producing a tableau vivant of the human animal's deep time (201). What makes "Pulvis et Umbra" even more remarkable, however, are the commonalities between its motifs and terminology and Stevenson's Strange Case. Written in 1887, just two years after the composition of the novella, the essay describes the origins and emergence of first life in terms that closely resemble those used by Jekyll to express Hyde's horrific ascendancy. In the novella, Hyde is the "energy of life," an "insurgent horror," the "slime of the pit," and the "amorphous dust"; he is "not only hellish but inorganic," embodying that which is "dead, and had no shape" and yet can "usurp the offices of life" (91). In "Pulvis et Umbra," life emerges out of the "vital putrescence of the dust," manifesting as "a pediculous malady; swelling in tumours that become independent," with organisms careening through untold generations of 
variation, "one splitting into millions, millions cohering into one" (201). Here the human is "a monstrous spectre," in his bid for survival a "thing to set children screaming," both "savagely surrounded" and "savagely descended," existing precariously in a world in which "the dew falls, and the generation of a day is blotted out" (205). Among other motifs, a generative dust carries through these two texts, freighted with both sacred and scientific resonances and yoking the fictional universe of Strange Case to Stevenson's nonfictional speculations. Titling his essay after a line from an ode by Horace, "pulvis et umbra sumus" (we are but dust and shadow), Stevenson proceeds to interrogate these constitutive parts, finding in them the language with which to characterize the human's shadowy beginnings. If the "pregnant phrases" of his essay are taken together with the language of his novella, we can see his vision of the process of emergent life in motion; from amorphousness to putrescence to agglutination, out of the "natal mud" springs a mass whose transmutations from a nebulous to an ever more structured state typify the unique mixture of Darwinian ideas and models of spontaneous generation that inform Stevenson's own evolutionary thought.

Stevenson's fascination with Darwinian evolution informs several recent studies, both of Strange Case and of his wider oeuvre, but this critical attention focuses mainly on his engagement with post-Darwinian evolutionary theory and evolutionist discourse. ${ }^{4}$ The most persuasive of these readings find in Mr. Hyde the embodiment of contemporary models of degeneracy and criminal deviance, with Hyde exhibiting the pathologies characteristic of the atavistic criminal. Most recently, Julia Reid argues that Strange Case "engages with the 'new sciences' of the degenerationist fin de siècle - criminology, criminal anthropology, evolutionist psychiatry, and sexology" (94). Reid's study builds upon the foundational work of Robert Mighall and Stephen Arata, both of whom perceive in the novella the presence of late-Victorian discourses about degeneracy and regression most notably articulated by the "psychiatric Darwinism" of the psychiatrist Henry Maudsley and the criminologist Cesare Lombroso. ${ }^{5}$ As Mighall shows, in 1862 Maudsley "employ[ed] an evolutionary framework to explain the importance of biological and hereditary factors in 'manufacturing' deviant or criminal individuals," arguing that the mind is subject to the "arrest or perversion of development" "and that "in the degeneration of [even] the highest intelligence there would appear to be a reversion to the lower form of human intelligence, or even sometimes to the type of animal mental development"' (143). By 1870, Maudsley formalized his theory of reversion, arguing in his book Body and Mind that there is "truly a brute brain within the man's" and that through psychological inquest we may "trace savagery in civilization, as we can trace animalism in savagery" (52-53) - and Mighall cites Strange Case as the earliest important work of fiction to have fully internalized these ideas (145). Similarly, with reference to Lombroso's model of the atavistic criminal who evidences the human capacity to return to the ancestral type, Arata observes that Hyde - described by Utterson as "troglodytic" effectively "reproduc[es] in his person the infancy of the human species," and that this, combined with his criminal deviance, aligns him with "late-Victorian anxieties concerning degeneration, devolution, and "criminal man"' and the threat these forces pose to middleclass values and the social order $(235,233)$. In contributing to this interpretive tradition, Reid adds the insight that "[d]espite its apparent allegiance to hereditary models of atavism," with its emphasis on Hyde's particular degeneracy being located in his effect and influence upon others, the tale "question[s] the hereditary nature of degeneration, and explains individual and cultural malaise in terms of environmental influence," thus negotiating a tension "within degenerationist theory, between heredity and infection by others" $(94,95)$. 
Readings like these - which align, for example, Stevenson's telegraphic observation on the novella that "My point is the identity with difficulty preserved" with contemporary anthropological and psychological etiologies of the degenerate mind and body - position Stevenson's evolutionary thought in largely cultural terms by favoring post-Darwinian evolutionist discourse about the endurance of 'primitive' agencies in modern 'civilized' culture that perceive the ongoing existence of the ancestral type as an erosive force, a drain on both the regressive individual and the people with whom s/he interacts. ${ }^{6}$ Such a framework casts the novella primarily as a chronicle of loss, seeing it as a modern gothic fable about a backward slide down the evolutionary ladder, but it just as readily sustains an interpretation focused upon the prevalence in the narrative of images of emergent life, growth, and development, and of Hyde in particular as exemplifying an organism in generative symbiosis with its environment. The aim of this essay is thus to place Stevenson's novella in conversation with Darwin's own models for variation, modification, competition, struggle, dependence, and adaptation, in order to illuminate how Stevenson's fiction both engages with and develops Darwinian thought about evolutionary processes. I argue that in Strange Case Stevenson provides a complex visualization of Darwin's "universal struggle for life," mobilizing the speculative capacity of fiction not only to observe the forces of flux that Darwin had taught his contemporaries to understand were ever-present and ongoing within and amongst all living things, but also to exceed Darwin's vision of transmutation by disconcertingly envisioning the specific characteristics of emergent life itself (Origin 115). ${ }^{7}$ It is in this sense that Strange Case answers Stevenson's notebook demand to make the evolutionary process "communicable and practical" reality ("Note Book" 301).

\section{II. “Emulously hoping to do better still”: Late-Victorian Struggles for Existence}

TO TRACE HOW STEVENSON materializes and thus communicates theoretical abstractions, submitting the unforeseeable and uncontrollable shaping mechanisms of the evolutionary process to visualization, it will be helpful first to address how the novel dramatizes the operations of natural selection itself, lending substance to the most elusive and encompassing metaphor in Darwin's conceptual arsenal. Once again, Stevenson's notebook provides telling clues. In an undated entry, Stevenson muses of natural selection that "[o]ne would have thought that its action was on the face of things" ("Note Book" 310). For Darwin, natural selection is a broad metaphor for the means by which the better adapted will tend to succeed over the less well-adapted. It is an idea that encompasses the pressures exerted over organisms as they compete for resources, and that explains - through reference to its various mechanisms (dependence, struggle, reproduction, variation, adaptation) - fluctuations of growth and dwindling in animal and plant populations. Natural selection is a causal force, the means by which variations are preserved and, in Darwin's phrase, "rendered definite," but its action is not reducible to any single visible effort (Origin 103). Instead, natural selection is a "power incessantly ready for action" through its agencies, which can be grouped together under the conceptual framework of the struggle for existence (Origin 115). Stevenson's various engagements with Darwinian evolution might best be thought of as thought experiments, by turns (as in "Pulvis et Umbra") offering an imaginative witnessing of the human amongst and constituted by the endless fluctuations taking place all around us, or (as in his 1887 essay "The Day After Tomorrow") sketching the human as correlative to the forces that shape it in the eternal war of nature, "his blood boil[ing] for physical dangers, pleasures, and triumphs" 
and "the furious contention with obstacles" that characterize the "sieve of dangers that we call Natural Selection" (252, 253). Throughout his visualizations of evolution, Stevenson situates the shaping forces of natural selection on the face of things, envisioning the evolutionary process in all its vital, dangerous, teeming presence. In other words, whereas for Darwin the procedures of natural selection must be understood in geological time, as the cumulation of myriad forces slowly and insensibly blocking and channeling species amidst the gradual uplift and subsidence of the planet's shifting ground, Stevenson concocts evolutionary dramas in which the threat of oblivion is sensate and real, and in which the agencies operating upon and through us are never out of mind. While Stevenson's essays crucially inform our understanding of his engagement with Darwinian thought, Strange Case stands as the grandest and most sustained of his evolutionary thought experiments, a tale of the human in/and nature that lends embodied substance to the tensions between the assertive force of anthropic will and the inhuman forces always acting to shape and circumscribe that will.

The tale opens with a portrait of Mr. Utterson, the lawyer-cum-detective who makes it his mission to unearth the secret behind Dr. Jekyll's strange relationship with the criminal Mr. Hyde. The embodiment of self-discipline and constraint, Utterson, we are told, "was austere with himself; drank gin when he was alone, to mortify a taste for vintages; and though he enjoyed the theatre, had not crossed the doors of one for twenty years" (31). Utterson's monk-like existence is further represented in the second chapter, in which he is pictured sitting by the fire, "a volume of some dry divinity on his reading desk" as he sternly awaits the midnight chime from the nearby church that permits him, according to selfimposed strictures, to "go soberly and gratefully to bed" (37). Through Utterson, Stevenson introduces two of the novella's central motifs. The first, as Arata recognizes, is the figure of the bourgeois gentleman, a highly-educated, respectable professional of social standing, embodied elsewhere in the text by Dr. Lanyon and of course "Henry Jekyll, M.D., D.C.L., LL. D., F.R.S., etc.," who together with Utterson stand in contrast to Hyde's wanton immorality (37). ${ }^{8}$ The second motif is the tension between a regulated and regulating self and those forces that defy or exceed regulation. In the broad context of the novella, Utterson will embody the rule of law that seeks to impose limits upon the dangerously subversive Hyde. More specifically, however, Stevenson's characterizations of Utterson stage the conflict between the desire to enact and impose one's own will and the unwilled forces that act upon and through us, regulating $u s$. In contrast to Utterson's rigid self-control, Stevenson writes that his "affections, like ivy, were the growth of time, they implied no aptness in the object" (31). Thus Utterson's friendships are an accident of circumstance and habit, resulting not from his own conscious preferences or from the inherent qualities of his associates, but from the slow engine of time operating upon him with ineluctable force. Despite his efforts to exert control over his own nature - i.e., to be the architect of his behavior - Utterson is shown to be subject to shaping mechanisms outside his control. By thus contrasting Utterson's determination to pit his will against the recalcitrant workings of his nature in the form of his predilections, tastes, and impulses against an image of time as a creeping organic force that works upon him whether or not he wishes it, Stevenson prefigures both the tale's wider preoccupation with the bourgeois subject's resolve to control the forces constitutive of his humanity and the ways in which those forces ultimately exceed his jurisdiction.

Following these characterizations, the narrative turns its attention to the surroundings into which Utterson and his cousin, Richard Enfield, have wandered on one of their Sunday excursions through London: 
It chanced on one of these rambles that their way led them down a by-street in a busy quarter of London. The street was small and what is called quiet, but it drove a thriving trade on the weekdays. The inhabitants were all doing well, it seemed, and all emulously hoping to do better still, and laying out the surplus of their gains in coquetry; so that the shop fronts stood along that thoroughfare with an air of invitation, like rows of smiling saleswomen. Even on Sunday, when it veiled its more florid charms and lay comparatively empty of passage, the street shone out in contrast to its dingy neighbourhood, like a fire in a forest; and with its freshly painted shutters, well-polished brasses, and general cleanliness and gaiety of note, instantly caught and pleased the eye of the passenger. (32)

Though Enfield and Utterson pass through the neighborhood as it lies comparatively dormant ahead of the trafficked commercial week, the spirit of productive rivalry that drives trade in the little marketplace is everywhere apparent and unmistakable. While the pleasingly welltended and freshly-painted shop fronts convey an atmosphere of order and a comforting sense of unity, the success story they tell is inevitably freighted with hints of the strife that powers capitalistic accomplishment. In the Origin Darwin writes that "[n]othing is easier than to admit in words the truth of the universal struggle for life, or more difficult - at least I have found it so - than constantly to bear this conclusion in mind" because when we look at nature in a general way, as we might a summer scene complete with flitting insects, chirping birds, and swaying trees above brightly-topped flower stalks, "[w]e behold the face of nature bright with gladness," losing sight of the furious activity that constitutes the precarious balance we observe (115-16). By contrast, Stevenson refuses to allow the "freshly painted shutters, well-polished brasses, and general cleanliness and gaiety of note" to conceal the merchants' emulous hope for ever-greater success, pausing instead to note the systems by which capitalism propagates itself through competition. The striking similarities between Stevenson's thriving district of London and a Darwinian model of the struggle for existence, everywhere apparent if one only looks for it, are particularly brought home by Stevenson's description of the shops' displays of abundance. With the surplus capital their success has brought them, vendors ornament their shop windows with commodities they hope will lend them the advantage over their competitors. Absent their inhabitants, the shops themselves transform into smiling saleswomen whose bared teeth, while on the surface signaling invitation for further commerce, nevertheless convey the fierce desperation as much inherent in the free market as in nature's ecosystems. ${ }^{9}$ In nature as in business, scarcity and abundance are coterminous, the former always dogging the steps of the latter, and the latter ever seeking the means to keep the former at bay.

But - and as Darwin is at pains to remind us - the struggle for existence cannot be reduced to emulous motive. Though change is often actuated by rivalry (as in Darwin's example, when "[t]wo canine animals in a time of dearth, may be truly said to struggle with each other which shall get food and life"), the strategies calculated to gain advantage in the marketplace ultimately only dimly resemble the largely unconsciously interconnected network of life that Darwin seeks to describe in his discussion of the "war of nature" by which "the vigorous, the healthy, and the happy survive and multiply" (Origin 116, 129). While in the broadest sense, as Elizabeth Grosz notes, the free market can be compared to natural selection insofar as it "is an equilibrating system, that adjusts itself according to the inputs, the sources for the production of wealth, and regulates the outputs, commodities, according to its own emerging and elaborating logic," Stevenson seems to recognize the limits of the 
analogy between capitalist struggle and production and the agencies of natural selection (35). The passage closes on an image of combustion: "the street shone out in contrast to its dingy neighbourhood, like a fire in a forest" (32). This appeal to the elemental force of fire symbolically reaffirms the inherency of natural struggles within capitalist interchange, while the encompassing image of the forest insists that the little marketplace bordering the entrance to Dr. Jekyll's laboratory be seen as just one component in the interlocking ecosystem of London at large. In contrast to the purposive and willed activity of merchants in pursuit of capital gain, the image of the site of their struggles as a riotous force of nature encircled by wilderness signals the narrative's underlying imperative to observe its characters and locations in their relationship to unwilled and unharnessed regulating forces of nature. As a forest fire, the street can be seen to play a vital role in maintaining the London habitat; whether purgative (in its incarnation as the consumptive reach of gentrification overwhelming dinginess) or merely destructive (as the devastating spread of its own likeness throughout varied London), the fire yokes Stevenson's mediations on struggle, competition, dependence, and adaptation in the marketplace to nature's cycles, wherein growth is always attended by decay, and blights of many kinds clear the way for new life to emerge. The London of Stevenson's Strange Case is thus not only irreducibly enmeshed in the forces of nature, but also from the outset acknowledged to be in a state of radical transformation.

In the above passage, Stevenson's simile points to a creative destruction burning at the heart of capitalism that, left unchecked, threatens to engulf all that surrounds it. In the novella more generally, images of consumptive fire recur in the person of Hyde and in the character of the fog that descends upon the city and subsumes it in a noxious murk. While the fog, like the marketplace, is compared to a fire - emitting "a glow of a rich lurid brown, like the light of some strange conflagration" - Hyde himself is equated with fire during his attack upon the peer Sir Danvers Carew, when he "br[eaks] out in a great flame of anger" $(48,46)$. In "Pulvis et Umbra" Stevenson begins his meditation on evolving life with a word on matter, deeming it "a thing which no analysis can help us to conceive; to whose incredible properties no familiarity can reconcile our minds," but nevertheless venturing that " $[t]$ his stuff, when not purified by the lustration of fire, rots uncleanly into something we call life" (200). In the essay, the devouring force of fire performs a cleansing rite ("lustration" comes from the Latin verb lustrare, to ceremonially purify) that clears away festering matter ahead of the next inevitable life-emitting putrefaction. Building on Darwin's processual vision of the struggle for existence - in which organic being "at some period of its life, during some season of the year, during each generation or at intervals, has to struggle for life, and to suffer great destruction" - Stevenson attributes a moral imperative to this inevitability (Origin 129). In "Pulvis et Umbra" lustrating fire may be said to perform an expiatory sacrifice, averting some unnamed evil in the "agglutinated dust" that it cleanses and prepares for new cohesion into vital form (201). In the novella, Hyde is broadly signified by fire and its properties; he is, after all, the result of Jekyll's application of heat to the combined mixture of "a simple crystalline salt of a white colour" and "a blood-red liquor," both "highly pungent to the sense" and seeming to contain "phosphorus and some volatile ether" that, once brought to "ebullition," may be seen to "boil and smoke" before cooling into the transformative tincture $(73,76,80)$. As the cleansing fire in "Pulvis et Umbra" consumes the living matter in its path, Hyde can be seen to blaze through the London of Strange Case, heedlessly laying waste - whether as the "Juggernaut" who "calmly" tramples the child in the first chapter, or as the "energy of life" 
that subsumes Jekyll at the novella's conclusion $(33,91)$. While the character of his infernal power may not on the surface appear to comprehend the felicitous cleansing properties of the essay's lustrating fire, I would argue that Hyde nevertheless serves a comparable function in the novella, embodying nature's obdurate insurgency in the face of human attempts to disavow its constitutive power upon, within, and all around us.

From the first publication of the novella, readers have sought to give form to Hyde's amorphousness. In his well-known review of 1886, Andrew Lang recognizes Hyde as the horrifying progeny of Jekyll's double life, in hideous contrast to the respectability of the novella's "successful middle-aged professional men"; in a letter to Stevenson that same year, John Addington Symonds characterizes Hyde as the embodiment of internal duality, calling him "the abysmal deeps of personality"; and an anonymous review in The Times shortly following the novella's January 1886 release distills Hyde to "a power of Evil."10 More recent criticism has sought to flesh out these early responses. For Irving S. Saposnik, Hyde is an "amoral abstraction" (212), the embodied repudiation of normative Victorian life - what Allen MacDuffie more recently characterizes as "a distinct production of the pressures and hypocrisies of middle-class respectability" (195). For Michael Davis, Julia Reid, and Stephen Heath, Hyde is the manifestation or behavior of disease. For Davis and Reid, he is a form of contagion, his deviance threatening to affect or infect those whom he encounters, either (for Davis) scandalizing a Victorian fantasy of unified and coherent selfhood by embodying fluid identity as psychological transformations "mapped in physical terms" (212), or (for Reid) through the "contagious nature of his atavism" (102). Similarly, for Heath, Hyde is the resurgence of sublimated sexual drives, a walking pathology threatening to overmaster the self-regulated Victorian subject. In the interest of uncovering the nature of the "something else" about Hyde that, for Utterson, generates the "impression of deformity" he conveys "without any nameable malformation," these responses have in common a tendency to understand Hyde as either the disease (a contagious malady that "transfigures . . . its clay continent" and inspires transformations in its audience, as is the case with the Sawbones, a healer who, upon seeing Hyde, "turn[s] sick and white with desire to kill him") or the symptom (the manifestation of pressures to sublimate whatever exceeds Victorian respectability) - or both, a pathology symptomatic of the status quo that threatens it with its own extermination (Strange 42, 41, 33). The critical tendency has therefore been to read Hyde as the embodiment of degeneration: he is a Freudian nervous illness attesting to Jekyll's arrested development, the erosive consequence of the suppressions deemed necessary for social order - or he is the ontogenetic return of the human's savage past, the outcome of evolutionary retrogression. I argue instead that Hyde is the manifestation of the principle of generation, displaying in his person both the origins and conditions of evolving life accelerated into a single life-cycle. In other words, in contrast to the marked tendency to focus on the Hyde that lies latent within us, I am concerned with Hyde as he embodies the forces to which we are ever and irrevocably subject, and which are constitutive of what we most basically are. Put simply, my focus here is the Hyde we live in.

\section{III. “Something downright detestable”: Hyde’s Revolt|ing Transmutation}

I CONTEND, THEN, THAT Hyde is at once a discrete physical presence, himself subject to morphological transformations, and a diffuse - though no less tangible - force, both signaling the ambient conditions in which we live and himself exercising a conversional capacity. As 
an environmental agency, Hyde's affective power is undeniable: as much as he is variously transformed throughout the novella, so too are the people with whom he comes in contact. From the suddenly-murderous Sawbones, to the women attending the trampled child who become toward Hyde "as wild as harpies," to Utterson, whose retiring nature gives over to frenetic activity and a single-minded obsession with Hyde's detection and exposure ("If he be Mr. Hyde . . . I shall be Mr. Seek"), others see Hyde, as critics have recognized, as an infectious presence, a kind of disease that mutates in each new host (34). But - and as he shows in "Pulvis et Umbra" - rather than seeing disease as a drain to vitality, Stevenson understands it as generative. There he writes that as matter "rots uncleanly into something we call life," it is "seized through all its atoms with a pediculous malady" (200). For Stevenson, disease is constitutive of evolutionary development, especially in the emergence of first life, which he describes as an illness "swelling in tumours that become independent, sometimes even (by abhorrent prodigy) locomotory" and as the "disease of the agglutinated dust," both "revolting" and "inconceivable," a thing to inspire "disgust" and to "set children screaming" (200, 201). Life is disease in the various senses of the word: it is a mutating, infecting, spreading influence, and to witness its pulsing presence is unsettling to say the least. In accelerating the processes of generation and development through competition, adaptation, and variation, Stevenson envisions "our rotary island loaded with predatory life, and more drenched with blood, both animal and vegetable, than ever mutinied ship" (201). Here, competing Juggernauts lurch continuously in perpetual unrest, and life is understood to be violent, bloody, and terrifying. The horror of Stevenson's novella is in part attributable to its witnessing of similar transformative forces actualized in the person of Hyde, who can be said to embody the blazing forces and energies of life.

In his "Full Statement of the Case," Jekyll describes the epiphany his scientific studies facilitate, saying that his work at "the laboratory table" teaches him to "perceive more deeply than it has ever yet been stated, the trembling immateriality, the mist-like transience, of this seemingly so solid body in which we walk attired" (79). Like Darwin before him, Jekyll realizes that the apparently stable form is in fact unfixed. This principle insight of the Origin was, however, weakened in the eyes of some critics by Darwin's inability to offer a comprehensive map of species change through reference to the transitional forms that lockstep one variation to another. The incompleteness of the existing fossil record forced Darwin to imaginatively ford its many gaps in order to paint a picture of the transitional links in species change, or, to use Jekyll's language, to trace the "mist-like transience" of species. In his chapter entitled "Difficulties on Theory" Darwin writes:

\footnotetext{
I lie under a heavy disadvantage, for out of the many striking cases which I have collected, I can give only one or two instances of transitional habits and structures in closely allied species of the same genus; and of diversified habits, either constant or occasional, in the same species. And it seems to me that nothing less than a long list of such cases is sufficient to lessen the difficulty in any particular case. (212)
}

Jekyll "perceive[s] more deeply than it has ever yet been stated" the shifting character of biological matter because his experiments unveil the fluid energies of life in Hyde, whose transitions, from "a little man," both "pale and dwarfish," to one "grown in stature" from a "more generous tide of blood," show the plasticity of his structure as it undergoes radical transformations $(33,41,85)$. 
Though he characterizes his account of Hyde trampling "calmly over the child's body" as "pedantically exact" $(34,33)$, Richard Enfield's attempts to describe Hyde's face and person to Utterson succeed only in communicating an unspecified or indeterminate quality in Hyde:

\begin{abstract}
$\mathrm{He}$ is not easy to describe. There is something wrong with his appearance; something displeasing, something downright detestable. I never saw a man I so disliked, and yet I scarce know why. He must be deformed somewhere; he gives a strong feeling of deformity, although I couldn't specify the point. He's an extraordinary looking man, and yet I really can name nothing out of the way. No, sir; I can make no hand of it; I can't describe him. And it's not want of memory; for I declare I can see him this moment. (35-36)
\end{abstract}

Searching for descriptive nouns, Enfield repeatedly lands on "something," a word that, when it is not a simple placeholder for an unremembered or immaterial detail in a recitation, designates an indistinction or an imprecision. Cataloguing the characteristics of one whom he "can see ... this moment," Enfield's language communicates Hyde's indefiniteness. Both "something" and "somewhere" attest to an essential spirit of displacement associated with Hyde: he is unfixed, fully actuated neither in person nor in language, reminiscent of the "thought that transcends existing means of expression" upon which Stevenson meditates in his notebook (300). But Hyde is no less material for being unfixed, and no less present for being a "something" whose distinguishing marks must be "somewhere." Indeed, since "something" is the very opposite of "nothing" - our most potent signifier of absence - Enfield's repetitive persistence in his choice of words forcefully conveys that Hyde be understood primarily as a presence. Hyde is some/thing, both indefinite and irreducibly material, an unspecific yet irrevocable ontological actuality.

Enfield's account is the first of many in the narrative that both communicates Hyde's persistent effect on his audience and characterizes what Dr. Lanyon later calls the "odd, subjective disturbance" of Hyde's presence. For Enfield, Hyde inspires dislike (36): for Utterson, he evokes an "unknown disgust" and "loathing" (42): for Dr. Lanyon, Hyde occasions a "disgustful curiosity" (74). Dr. Lanyon ventures a preliminary diagnosis of Hyde's abnormality in registering his agitation at witnessing in him the "remarkable combination of great muscular activity and great apparent debility of constitution" (74). Perceiving in the person of Hyde an anatomical insurgency, in which expansion and growth in one quarter is attended by decline and decay in another, Lanyon recognizes Hyde's transitionality, to his fatal dismay beholding in him the struggle between competing forces made visible. For Enfield and Utterson, Hyde's transformative quality is no less apparent, though it is characterized more vaguely as "deformity." To Enfield, Hyde "must be deformed somewhere," and to Utterson, he is the "impression of deformity," but both witness in Hyde the action of distortion, as if some mutative morphic power surpassing their visual grasp were twisting and distending him before their very eyes. Characteristics of Hyde's embattled body seem to echo through "Pulvis et Umbra," where the rotting substance of the earth is described as "something we call matter: a thing which no analysis can help us to conceive; to whose incredible properties no familiarity can reconcile our minds" (200; emphasis added). Like this irreducible matter, Hyde simultaneously seems to exceed all description and to encompass all things: he is "something displeasing" (35), a "Juggernaut" (33), "dwarfish" (42), "like Satan" (34), "troglodytic" (42), a "cancer" (43), a "disgrace" (43), "ape-like" (46), a "storm" (46), a "flame" (46), a "connoisseur" (49), armed with "good taste" (49), a "thing" (64), "dead" (91), the "raging 
energies of life" (91), "inorganic" (91), and "the slime of the pit" (91). And like the pulsing, writhing life-matter of Stevenson's essay, that "strikes us with . . . disgust" when we pause on its "revolting and inconceivable" operations accelerated to a fever pitch, Hyde elicits revulsion and fear in his onlookers $(200,201)$.

\section{IV. "Shifting insubstantial mists": The London Fog as Prebiotic Soup}

UNTIL NOW, I HAVE largely traced Stevenson's thought experiments as they render visible component parts of the struggle for existence and the huge movements of species change explicitly theorized by Darwin in the Origin and elsewhere. Throughout, we see how Stevenson often imagines past the limit-points set by Darwin, and in the previous section we observe his thought reaching to giddy heights as he envisions Hyde's body as the manifestation of transitionality, in which the reconfigurations of his tensile frame seem to surpass any known models for metamorphosis within a single life-cycle (his transformations do not recall the morphic stages undergone by beetles, frogs, or butterflies, for instance), signaling instead the disorderly character of consecutive stages of variation and modification made simultaneously manifest. In what follows, I turn to what is perhaps Stevenson's most striking extrapolation, his envisioning of the very origins of life, in which we can perceive the novelist publicly intuiting the tenor of the naturalist's largely private thoughts on primum vitae.

In an 1838 entry in what is known as "Notebook C," Darwin speculates on the chemical origins of first life from non-living matter, writing that " $[t]$ he intimate relation of Life with laws of Chemical combination, \& the universality of latter render - spontaneous generation not improbable. - " (Notebooks 269). Twenty-one years later, in the first edition of his Origin of Species, Darwin concludes his famous contemplation of the "entangled bank" with a sanguine and productively vague remark about the origins of life: "There is grandeur in this view of life, with its several powers, having been originally breathed into a few forms, or into one" (459). In the second and every subsequent edition, Darwin amended this passage, bending to public will by adding the "Creator" as the source of this life-breath. None of the six editions of the Origin ever supplied readers with Darwin's scientific views on the emergence of the first life-forms. Though the third (1861) edition tantalizingly includes the remark that "it is no valid objection that science as yet throws no light on the far higher problem of the essence or origin of life," it leaves the reader to her own devices in the discovery of such illuminations (514). By March of 1863, Darwin could exclaim decisively in a letter to his friend Joseph Dalton Hooker that "it is mere rubbish thinking, at present, of origin of life; one might as well think of origin of matter" (Correspondence 278). ${ }^{11}$ This assertion was followed, three weeks later, by Darwin's publication in the Athencum of a scathing response to Richard Owen's review of Dr. Benjamin Carpenter's the Introduction to the Study of the Foraminifera:

Your reviewer believes that certain lowly organized animals have been generated spontaneously that is, without pre-existing parents - during each geological period in slimy ooze. A mass of mud with matter decaying and undergoing complex chemical changes is a fine hiding-place for obscurity of ideas. ("Heterogeny" 554)

Though Darwin does not rule out the possibility of an original spontaneous generation, even speculating about "the reeking atmosphere . . . charged with carbonic acid, nitrogenized 
compounds, phosphorus, \&c," he objects to Owen's concept of the periodical emergence of new life enduring in spite of the threat posed by extant organisms ("Heterogeny" 554). Although he admits in the Athenaum piece to the unscientific grounds for his claim of an original life-breathing "Creator," it may be speculated that Darwin does not remove Primum Mobile from later editions of the Origin because of a firmly-held belief that while the circumstances for the emergence of new life might very well recur in each geological period, the chances of organic life succeeding to the locomotory stage in spite of the competing agencies of natural selection are infinitesimal, and so he commits himself to a single life-emitting event and chooses the path of least resistance in characterizing it. $^{12}$

On the other hand, it is clear that Darwin found the idea of spontaneous generation at least speculatively compelling. In a letter to Hooker from 1 February 1871, Darwin writes:

It is often said that all the conditions for the first production of a living organism are now present, which could ever have been present. - But if ( $\&$ oh what a big if) we could conceive in some warm little pond with all sorts of ammonia \& phosphoric salts, - light, heat, electricity \&c present, that a protein compound was chemically formed, ready to undergo still more complex changes, at the present day such matter $\mathrm{w}^{\mathrm{d}}$ be instantly devoured, or absorbed, which would not have been the case before living creatures were formed. ${ }^{13}$

Combining his notebook notation on "laws of Chemical combination" with his Athenceum musing about "the reeking atmosphere," Darwin envisions a prebiotic soup from which elemental forces might forge strings of living protein. Five months earlier, in his September 1870 presidential address to the British Society for the Advancement of Science, T. H. Huxley had championed "the hypothesis of Abiogenesis," the principle that "living matter may be produced by not living matter" (236). Arguments in support of the theory that biological processes have a chemical basis, and that original life probably emerged without the assistance of organic compounds, had by this point long been gaining prevalence, as Huxley's speech attests, but it is not until Stevenson debuts Mr. Hyde - the chemically formed protean life finding the means to survive without being "instantly devoured, or absorbed" - that the whole process of life, from first emergence to the outcompeting of rival forces, was given such full and vivid imagining. ${ }^{14}$

In "Pulvis et Umbra" life springs from "natal mud," whose rotting transforms "dust" into "atoms" that undergo variation and modification ("one splitting into millions, millions cohering into one") until they become "locomotory" (200). In Strange Case, life emerges as the result of a chemical tincture composed of "a simple crystalline salt" with a "phosphorus" odor (73). Encompassing contemporary hypotheses of the origins of life, the two texts envision the conditions necessary for survival. While the first life-form in "Pulvis et Umbra" emerges from lustratred earth, "coming detached out of its natal mud, and scurrying abroad" unmolested to become the parent of generations that will undergo the war of nature in which organisms "prey upon each other, lives tearing other lives to pieces," Hyde is new life thrust directly into the fray of struggle and competition (200-1). As if in answer to Darwin's objection, Stevenson imagines Hyde arising assisted out of the modern buildingblocks of life, amidst which the chemical murk of the London fog might constitute not only the "unknown impurity which lent efficacy to the draught," but also a shepherding agency, 
sheltering Hyde from devouring and absorbing forces (92). For Hyde, the London fog in Strange Case is far more than a mere atmospheric flourish: it is both generative medium and evolutionary advantage, coexisting with and enabling him in the violent struggle for survival. Like the fog, Hyde is described as "shifting, insubstantial mists" (37), and like Hyde, the fog is "embattled," warring with winds that "continually charg[e] and rou[t]" the foul mixture as it "lower[s] over heaven," clasping London in its choking embrace (47). Through the figure of the fog, Stevenson's "clatter[ing]" (40) London is continually "rolled over" (46) by "a great chocolate-coloured pall" (47) that transforms the "vast hum . . . of the city" (40) into a muffled, "drowned" (52) labyrinth of streets, "where the lamps glimme[r] like carbuncles" (52). Endowed with an almost anthropomorphic density, the fog represents a creeping environmental threat, a noxious climatic miasma unleashed by industrial overreaching. As the fog palls the city, cloaking it and draining its vitality, so Hyde vampirically gains in strength "with the sickliness of Jekyll" (91). Whereas, like "some city in a nightmare" (48), London drowns in the fog's noxious and dense mixture of soot, smoke, and mist, Hyde thrives, growing in stature, his "faculties . . sharpened to a point," his veins flooded with a "more generous tide of blood" (85). Better suited to his environment, Hyde adapts where others decline, and through him Stevenson traces the evolutionary commingling of growth and decay.

In the novella, Hyde is both "troglodytic" and "ape-like," recapitulating in his person human evolution in both civilizational and geological time $(42,46){ }^{15}$ Combining in his own lifespan the caveman and our distant hominid ancestor, Hyde anticipates what in his 1888 essay "The Manse" Stevenson describes as the immutable "aboriginal frisking in the blood" (65), the same shadowy atavism which, in another essay of that same year entitled "Pastoral," he heralds (with a nod to Darwin's Descent of Man) as "man's morning . . . often described as Probably Arboreal," "the trunk and aboriginal taproot of the race" who persists in us all, forever tingling "our civilized nerves" with "his rude terrors and pleasures" $(57,58) .{ }^{16}$ Though he recalls the origins of life and the human's antique past, Hyde also more generally embodies the complex forces relentlessly acting upon us in the modern era. As in the case of the murder of Sir Danvers Carew, the "aged and beautiful gentleman" endowed with "a well-founded self content" - during which Hyde manifests elementally as both a "storm" and a "flame," staging the inevitable forces of nature laying waste to the frail "old world," carving out a niche for robust new life - Hyde is both a discrete organism competing for survival and an environmental agency, selecting according to its ecosystem's conditions, irrespective of a competing organism's ancient pedigree and apparent rootedness (78). In the published version of the murder, Stevenson emphasizes Hyde's disruption of the class system, as "the audibly shattered" bones of Sir Danvers Carew metonymically announce Hyde's threat to the patrician "old world" (46). In the manuscript version of the tale, however, Hyde's victim is a Mr. Lemsome, who is described as being "anoemically pale," and whose death is thus if not warranted at least expected according to the unsparing dictates of evolutionary logic. ${ }^{17}$ Across the two texts, Stevenson surveys Hyde's effect in both cultural and biological terms. Sir Danvers' "very pretty manner of politeness" and Mr. Lemsome's pallid aspect are no match for Hyde's unruly and blazing vitality, and in this case as elsewhere Hyde figures in the novella's ecosystem as a merciless unstoppable force, embodying at once a furiously competing organism, the competitive and adaptive agencies of natural selection, and the hammer-stroke of inevitable death, and even, perhaps, extinction (46). 


\section{The Hyde We Live In: The Late-Victorian Anthropocene}

THE FOG THAT PERMEATES the London of Strange Case - such a fixture of life by 1886 that Stevenson could refer to it as "the first . . . of the season" (47) and so widespread that it is seen to "lie thickly" "even in the houses" (50) - represents the meteorological outcome of unchecked resource consumption in the heady climate of nineteenth-century industrial, scientific, and technological revolution. Whereas in 1839 Darwin could write cheerfully to his cousin W.D. Fox that "there is nothing like [London's] quietness - there is a grandeur about its smokey fogs, \& the dull distant sounds of cabs and coaches" (234), by 1886 Stevenson's London is "drowned" (52) by this creeping threat, whose "embattled vapours" (47) seem almost to have gained dominion over the earth's rotations in their ability to transform the first light of morning into "the degrees and hues of twilight" (48). Indeed, the fogs of the 1880s were unrivalled even by the great disasters of 1814 and 1873, in which the "particulates," as they were sometimes called, mingled with the naturally-occurring mists of the Thames to create a dense gloom, made up of flakes of black soot, smoke, and other fumes from factory emissions, so thick that people wandered, to their deaths, into traffic, over the tops of staircases, and into the Thames, and so toxic that urban mortality rates from various lung ailments radically increased when fogs descended in winter and spring. ${ }^{18}$ By the time Stevenson wrote Strange Case, human activity seemed both to be changing the climate and engendering new threats to survival. ${ }^{19}$ A byproduct of the unregulated growth of industry and population increasing geometrically in the dizzy interchange of supply and demand that fuels capitalist competition, the London fog announces capitalism's unsustainability. ${ }^{20}$ In Strange Case, Stevenson mobilizes the fog as one of the natural checks in his complex Darwinian ecosystem, symbolically intertwining the tale's atmosphere with its "villain," who, together, overmaster the novella's bourgeois subjects, all of whom seek to pit their will against the forces of nature, heedless of the consequences.

The conspicuous celibacy of the novella's male characters has been remarked upon by numerous critics. ${ }^{21}$ In embodying the forces of growth, energy, and struggle, Hyde stands in opposition to the evolutionary arrest suggested by Jekyll, Lanyon, Utterson, Sir Danvers, and Enfield. In contrast to Hyde's embodiment of the generative principle, Jekyll seeks to harness nature's capacities and to select for himself, vivisecting his own spirit to rid himself of the unruly forces within, dividing where nature would multiply. While in Jekyll's particular case, celibacy may constitute the bourgeois subject's assault on nature's reproductive capacity, more generally it operates in the novella as a selfimposed Malthusian check symptomatic of a highly successful society whose members are so certain of their triumph that they no longer feel the need to pass on their genes. Populating his tale with men who seek to stand apart from the teeming forces all around them, Stevenson confronts the bourgeois subject with forces majeures in the form of Hyde and the fog, who interactively represent nature's recalcitrant will to reproduce even in the face of celibacy. Both products of incursions into the natural order, Hyde and the fog refute human attempts to harness nature's fecundity. Strategically "lift[ing]" here, "settl[ing]" there, and "show[ing]" Utterson through Soho, "cut[ting] him off" to direct his movements, the fog, the byproduct of capitalist competition, threatens to outcompete the human, ostensibly nature's greatest competitor (48). Where Jekyll attempts to divide or to reduce, Hyde counters with growth. Where Utterson, Lanyon, and Enfield choose celibacy, Hyde is the refutation of abstinence. Where the bourgeois subject pits his will against the recalcitrant forces of nature, 
Hyde forcefully highlights the strength of nature as an adversary, returning the violence constitutive of the subject back upon itself and countering intransigency with trembling immateriality.

Stevenson's Strange Case has long been established as one of our most salient cultural narratives, amounting almost to a cultural trope, training us to perceive the "war among [our] members" as an inevitability of human nature (78). Like all enduring literature, whose contemporary relevance can seem uncanny, Strange Case speaks to the present. In its portrait of human attempts to overcome the forces of nature, it heralds the anthropogenic condition. Granting Crutzen's premise that the invention of the steam engine in the late eighteenth century marked our entrance into a new geological era characterized by cataclysmic human-made climatological and biogeographical changes - or, indeed, any of the other competing hypotheses delineating the onset of the modern geological era in which the human constitutes a telluric force - we can perceive in Strange Case a narrative of anthropogenic excess, in which Hyde seems to constitute the production of a new anthropogenic subject. $^{22}$

If we accept that Hyde embodies at once the forces out of which we emerge and a new emergent lifeform (co-created by human action and environmental conditions and fully adapted to his inhospitable surroundings), then he can be seen to demarcate what Chakrabarty, in another context, describes as a "fundamental change in the human condition" at the dawning of the Anthropocene (14). Chakrabarty suggests that the human as a "geophysical force" in the Anthropocene is "neither a subject nor an object" since a "force is the capacity to move things" and is thus a "nonontological agency" (13). Hyde, who is some/thing, an existence that defies precise ontological categorization but is nevertheless irreducibly present, and who is at once determined by his environment and a determinant of the conditions of existence, offers a means of apprehending how the Anthropocene redraws the boundary-lines of human subjectivity. I would like to suggest that in this mode of existence, the agonistic Darwinian paradigm of the human individual as both (in Gillian Beer's words) "vehicle and dead end," participating "in the evolutionary process . . . only through generation, [and] not through any happening in its own life cycle," is supplanted by a geo-anthropic paradigm in which the yawning divide between individual and species collapses because the individual is borne into a world co-created by a human nature so powerful as to have a hand in determining the geophysical conditions of existence (38). Thus the paradigm of the Anthropocene recognizes human agency, but the character of that agency is perhaps best described as catastrophic, for it has actively willed a condition that threatens its very existence. In Stevenson's story we find a dramatization of Hyde as the anthropogenic subject wherein he is both a manifestation of this catastrophic agency and its instrument.

This is, in fact, the Hyde we live in. In its broad apprehension of the modern condition, Strange Case speaks to our present both in prescient detail - in its portrait of Hyde confronting the celibate Victorian with reproduction's terrifying inevitability the novella seems to chart our present moment, in which we live in fear of the cataclysmic effect of overpopulation and yet cannot help but grow - and in paradigmatic terms, for in our present era we are all both products of anthropic catastrophic agency and also its instruments.

\section{University of Wisconsin Oshkosh}




\section{NOTES}

1. While editors and critics have often inserted the article "The," I will use Stevenson's original title for the novella.

2. See "Selections From His Note Book," 301-4, for Stevenson's further meditations on language and "word-symbols."

3. All quotations are from the Broadview edition of The Strange Case.

4. A growing number of studies have demonstrated intersections between Stevenson's work and various scientific fields that emerged in the latter half of the nineteenth century, including degeneration theory, cultural anthropology, evolutionary psychology, theories of the conscious and unconscious mind, physiological psychology, and thermodynamics. For degeneration theory see Arata, "The Sedulous Ape: Atavism, Professionalism, and Stevenson's Jekyll and Hyde"; for evolutionary psychology, evolutionary anthropology, and degeneration theory, see Mighall, A Geography of Victorian Gothic Fiction: Mapping History's Nightmares and Reid, Robert Louis Stevenson, Science, and the Fin de Siècle; for the Freudian uncanny and dream psychology see Towheed, "R.L. Stevenson's Sense of the Uncanny: "The Face in the Cheval-Glass"'; for late-Victorian theories of mind see Stiles, "Robert Louis Stevenson's Jekyll and Hyde and the Double Brain" and Davis, "Incongruous Compounds: Rereading Jekyll and Hyde and Late-Victorian Psychology"; for energy science and an ecocritical reading of Stevenson's fiction see MacDuffie, Victorian Literature, Energy, and the Ecological Imagination. Though not, strictly speaking, a study of a scientific theory, Clayson's essay, "'Steadfastly and securely on his upward path': Dr. Jekyll's spiritualist experiment," places the novella in conversation with Alfred Russell Wallace's spiritualist revision of Darwinian natural selection, arguing that Jekyll's failed experiment can be read as an attempt to progress the human species toward ever-greater perfection.

5. See Mighall's A Geography of Victorian Gothic Fiction, 143, 259; see also "Psychiatric Darwinism," in Skultans' Madness and Morals, especially pages 206-13.

6. For a partial transcript of Stevenson's letter to Lang, see the "Composition and Production" section of Linehan's Norton Critical Edition of Strange Case, 81.

7. Unless otherwise stated, all citations of the Origin are from the 1859 edition.

8. See Arata, "The Sedulous Ape" and Fictions of Loss.

9. See Grosz, 35-6, for a discussion of laissez-faire economics and Adam Smith's An Inquiry into the Nature and Causes of the Wealth of Nations (1776) in relation to Darwinian evolution.

10. See the "Reception" section of Linehan's Norton Critical Edition, 93 and 98.

11. By 1868 Darwin writes conclusively in The Variation of Animals and Plants under Domestication that "the first origin of life on this earth, as well as the continued life of each individual, is at present quite beyond the scope of science" (1: 12).

12. Darwin accedes to Owen's criticism of his own explanation of primordial life's original inhalation, writing that "in a purely scientific work I ought perhaps not to have used such terms; but they well serve to confess that our ignorance is as profound on the origin of life as on the origin of force or matter" ("Heterogeny" 554).

13. Francis Darwin footnotes part of this letter in his 1887 Life and Letters, 18n; Browne cites the letter in Charles Darwin: The Power of Place, 392; the full transcript can be found in the Darwin Collection at Cambridge, 94: 188-89.

14. For an excellent summary of Darwin's writing on the origin of life, see Peretó et al., "Charles Darwin and the Origin of Life."

15. For discussions of Hyde as an ancestral ape and Huxley's Man's Place in Nature (1863) as a possible source for Hyde-as-troglodyte, see Bland's Generation of Edward Hyde, 257-67.

16. See Darwin's The Descent of Man, where he writes that " $[w]$ ] thus learn that man is descended from a hairy quadruped, furnished with a tail and pointed ears, probably arboreal in its habits, and an inhabitant of the Old World" (678).

17. See Veeder and Hirsch, Dr. Jekyll and Mr. Hyde After One Hundred Years, 24. 
18. For more on the London fogs, see The Times, 5 Jan. 1814; Section X, "Extraordinary Fog" in the Annals of Philosophy, 1814; Luckin's “"The heart and home of horror': the Great London Fogs of the Late Nineteenth Century"; Brimblecombe's The Big Smoke, 108-35; Ridenhour's In Darkest London, 21-22, 31, 140. And for a recent study of the London fog that includes a very useful discussion of the function of environmental pollution in Strange Case see Taylor, The Sky of Our Manufacture.

19. Meteorologists like Rollo Russell were beginning to warn late Victorians that the dense and oppressive air that caused many "painful and constricted" breathing was responsible for radical increases in urban mortality rates (London Fogs 24; Smoke 9).

20. In his excellent discussion of the unsustainability of Stevenson's fictional world, MacDuffie details the novella's "emphasis on resource exhaustion," concluding that in "attempt[ing] to yoke the desire for an unbounded life to a bounded world, to imagine that endless transformations can be produced by a finite supply of resources," the text dramatizes the "recklessness of dreams of endless supplies of energy, and of the belief that such supplies are available for the realization of every individual desire" $(192,196)$.

21. See Heath, "Psychopathia," 104, and Veeder, "Children," 103, 117. See also Gwynn's likening of Stevenson's Londoners to "a community of monks" (130). Some critics ascribe the absence of women in the novella to an exemplification of London's homosexual subculture. Showalter, for example, reads the story a "fable of ... homosexual panic, the discovery and resistance of the homosexual self" (107).

22. Various competing dates have been advanced for the dawn of the Anthropocene. From the end of the last Ice Age and the advent of agriculture in the early phases of the Holocene, during which a milder climate "allowed the increase of the human population" and enabled it to assume "its role as a geologic force" (Certini and Scalenghi 246), to the "great transition" represented by the "thermo-industrial" revolution of the nineteenth century (following James Watts' release of his design for the steam engine in 1784) (Steffen et al. 847), to the "golden spike" represented by the biospheric after-effects of the first atomic detonation on July $16^{\text {th }}, 1945$ - this particular date was chosen by a working group of the Geological Society of London because "the isotopic by-products of bomb testing provide a distinctive marker horizon in ice cores, ocean and lake sediments, and soils" (Ruddimen et al. 38). Though the debate about its date of onset continues, and although the International Commission on Stratigraphy has yet to issue its determination on whether the environmental changes provoked by the industrial era have been sufficient to leave behind what Zalasiewicz et al. have called a "stratigraphic signature" marking a boundary line between the current era and the Holocene (4), few would deny that we are living through an era marked by the "impoverishment and artificializing of the earth's living tissue" in which the conditions of our existence are actively transformed by the after-effects of anthropic will (Bonneuil and Fressoz xi). For a comprehensive discussion of the Anthropocene and arguments in favor of its recognition as a new epoch in Earth history inaugurated by the industrial growth of the nineteenth century, see Steffen et al.'s "The Anthropocene: Conceptual and Historical Perspectives" and Zalasiewicz et al.'s "Are we now living in the Anthropocene?"

\section{WORKS CITED}

Anonymous. "Extraordinary Fog." Annals of Philosophy: Magazine of Chemistry, Mineralogy, Mechanics, Natural History, Agriculture and the Arts. Vol. 3, 16 vols. Jan.-June 1814. London: C. Baldwin, 1814.

Anonymous. "Monday, Jan. 5." The Times of London, 5 Jan. 1814.

Arata, Stephen. Fictions of Loss in the Victorian Fin de Siècle. Cambridge: Cambridge UP, 1996.

Arata, Stephen. "The Sedulous Ape: Atavism, Professionalism, and Stevenson's Jekyll and Hyde." Criticism 37.2 (1995): 233-59.

Beer, Gillian. Darwin's Plots: Evolutionary Narrative in Darwin, George Eliot and Nineteenth-Century Fiction. Cambridge: Cambridge UP, 2000. 
Bland, Jay. Generation of Edward Hyde: The Animal Within, from Plato to Darwin to Robert Louis Stevenson. Brussels: Peter Lang, 2010.

Bonneuil, Christophe and Jean-Baptiste Fressoz. The Shock of the Anthropocene: The Earth, History and Us. Translated by David Fernbach. London: Verso, 2015.

Brimblecombe, Peter. The Big Smoke: A History of Air Pollution in London Since Medieval Times. London: Methuen, 1987.

Browne, Janet. Charles Darwin: The Power of Place. Vol. 2, 2 vols. Princeton: Princeton UP, 2002.

Certini, Giacomo and Riccardo Scalenghi. "Holocene as Anthropocene." Science 349.6245 (2015): 246.

Chakrabarty, Dipesh. "Postcolonial Studies and the Challenge of Climate Change." New Literary History 43.1 (2012): 1-18.

Clayson, Sara. "'Steadfastly and securely on his upward path': Dr. Jekyll's Spiritualist Experiment." Journal of Stevenson Studies 2 (2005): 51-69.

Crutzen, Paul J. "The Geology of Mankind.” Nature 415 (2002): 23.

Davis, Michael. "Incongruous Compounds: Re-reading Jekyll and Hyde and Late-Victorian Psychology." Journal of Victorian Culture 11.2 (2006): 207-25.

Darwin, Charles. The Descent of Man, and Selection in Relation to Sex. 1871. Ed. and intro. James Moore and Adrian Desmond. London: Penguin Books, 2004.

Darwin, Charles. "The Doctrine of Heterogeny and Modification of Species." Athenceum: Journal of Literature, Science, and the Fine Arts 1852 (25 Apr. 1863): 554-55.

Darwin, Charles. "Notebook C." Charles Darwin's Notebooks, 1836-1844. Ed. Paul H. Barrett et al. Ithaca: Cornell UP, 1987.

Darwin, Charles. The Origin of Species by Means of Natural Selection, Or the Preservation of Favoured Races in the Struggle for Life. 1859. $1^{\text {st }}$ ed. Ed. and intro. J. W. Burrow. London: Penguin, 1968.

Darwin, Charles. The Origin of Species by Means of Natural Selection, Or the Preservation of Favoured Races in the Struggle for Life. $3^{\text {rd }}$ ed. London: John Murray, 1861.

Darwin, Charles. The Variation of Animals and Plants under Domestication. Vol. 1. 2 vols. London: John Murray, 1868.

Darwin, Charles. "To W. D. Fox, 24 October [1839]." The Correspondence of Charles Darwin, 1837-1843. Vol. 2, 12 vols. Ed. Frederick H. Burkhardt, et al. Cambridge: Cambridge UP, 1986. 234-35.

Darwin, Francis. The Life and Letters of Charles Darwin, Including an Autobiographical Chapter. Ed. Francis Darwin. Vol. 3. 3 vols. London, 1887.

Grosz, Elizabeth. The Nick of Time: Politics, Evolution, and the Untimely. Durham and London: Duke UP, 2004.

Gwynn, Stephen. Robert Louis Stevenson. London: Macmillan, 1939.

Heath, Stephen. "Psychopathia Sexualis: Stevenson's Strange Case." Critical Quarterly 28.1\&2 (1986): 93-108.

Huxley, Thomas Henry. "Biogenesis and Abiogenesis [1870]." 1894. Collected Essays Volume 8, Discourses: Biological and Geological. Vol. 8. 9 vols. Cambridge: Cambridge UP, 2011. 229-71.

Luckin, Bill. "“The Heart and Home of Horror': The Great London Fogs of the Late Nineteenth Century." Social History 28.1 (2003): 31-48.

MacDuffie, Allen. Victorian Literature, Energy, and the Ecological Imagination. Oxford: Oxford UP, 2014

Maudsley, Henry. Body and Mind: An Inquiry into Their Connection and Mutual Influence, Specially in Reference to Mental Disorders. London: Macmillan, 1870.

Mighall, Robert. A Geography of Victorian Gothic Fiction: Mapping History's Nightmares. Oxford: Oxford UP, 1999.

Peretó, Juli et al. "Charles Darwin and the Origin of Life." Origins of Life and Evolutionary Biospheres 39 (2009): 395-406.

Reid, Julia. Robert Louis Stevenson, Science, and the Fin de Siècle. New York: Palgrave, 2006.

Ridenhour, Jamieson. In Darkest London: The Gothic Cityscape in Victorian Literature. Lanham: Scarecrow P, 2013. 
Ruddimen, William et al. “Defining the Epoch We Live In: Is a Formally Designated 'Anthropocene' a Good Idea?" Science 348.6230 (2015): 38-39.

Russell, F. A. R. (Rollo). London Fogs. London: Edward Stanford, 1880.

Russell, F. A. R. (Rollo). Smoke in Relation to Fogs in London. London: National Smoke Abatement Institute, 1889.

Saposnik, Irving S. “The Anatomy of Dr. Jekyll and Mr. Hyde.” Studies in English Literature, 1500-1900. 11.4 (1971): 715-31.

Showalter, Elaine. Sexual Anarchy: Gender and Culture at the Fin de Siècle. New York: Viking, 1990.

Skultans, Vieda. Madness and Morals: Ideas on Insanity in the Nineteenth Century. London: Routledge, 1975.

Steffen, Will et al. "The Anthropocene: Conceptual and Historical Perspectives." Philosophical Transactions of the Royal Society 1938.369 (2011): 842-67.

Stiles, Anne. "Robert Louis Stevenson's Jekyll and Hyde and the Double Brain." Studies in English Literature, 1500-1900 46.4 (2006): 879-900.

Stevenson, Robert Louis. “The Day After Tomorrow.” 1887. The Works of Robert Louis Stevenson, Virginibus Puerisque Ethical Papers Edinburgh: Picturesque Notes. Vol. 2. 32 vols. New York: Scribner, 1925. 245-55.

Stevenson, Robert Louis. The Letters of Robert Louis Stevenson. Vol. 3. 4 vols. Ed. Sidney Colvin. New York: Scribner, 1925.

Stevenson, Robert Louis. “The Manse.” 1888. The Works of Robert Louis Stevenson: Memories and Portraits, Random Memories, Memoirs of Himself. Vol. 13, 32 vols. New York: Scribner, 1925. 59-65.

Stevenson, Robert Louis. "Pastoral." 1888. The Works of Robert Louis Stevenson: Memories and Portraits, Random Memories, Memoirs of Himself. Vol. 13, 32 vols. New York: Scribner, 1925. 51-58.

Stevenson, Robert Louis. "Pulvis et Umbra." 1888. The Works of Robert Louis Stevenson: Memories and Portraits, Random Memories, Memoirs of Himself. Vol. 13.32 vols. New York: Scribner, 1925. 199-205.

Stevenson, Robert Louis. "Selections from His Note Book." The Works of Robert Louis Stevenson: Memories and Portraits, Random Memories, Memoirs of Himself. Vol. 13, 32 vols. New York: Scribner, 1925. 297-321.

Stevenson, Robert Louis. Strange Case of Dr. Jekyll and Mr. Hyde. 1886. Norton Critical Edition. Ed. Katherine Linehan. New York: Norton, 2003.

Stevenson, Robert Louis. The Strange Case of Dr. Jekyll and Mr. Hyde. 1886. Ed. and intro. Martin A. Danahay. $2^{\text {nd }}$ ed. Peterborough, ON: Broadview, 2005.

Taylor, Jesse Oak. The Sky of Our Manufacture: The London Fog in British Fiction from Dickens to Woolf. Charlottesville: U of Virginia P, 2016.

Towheed, Shafquat. "R.L. Stevenson's Sense of the Uncanny: "The Face in the Cheval-Glass." English Literature in Transition 42.1 (1999): 23-38.

Veeder, William. "Children of the Night: Stevenson and Patriarchy." Robert Louis Stevenson. Ed. and intro. Harold Bloom. London: Chelsea House, 2005.

Veeder, William, and Gordon Hirsch, eds. Dr. Jekyll and Mr. Hyde After One Hundred Years. Chicago: U of Chicago P, 1988.

Zalasiewicz, Jan et al. "Are we now living in the Anthropocene?" GSA Today 18.2 (2008): 4-8. 